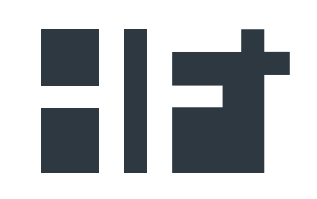

INSTITUTE OF RETAIL ECONOMICS

\title{
THE DECLINE OF SMALL CITIES: INCREASED COMPETITION FROM EXTERNAL SHOPPING MALLS OR LONG-TERM NEGATIVE TRENDS?
}

\author{
SVEN-OLOV DAUNFELDT, OANA MIHAESCU \& \\ NIKLAS RUDHOLM
}




\title{
The decline of small cities: Increased
}

\section{competition from external shopping malls or}

\section{long-term negative trends?}

\author{
Sven-Olov Daunfeldt ${ }^{\S}$, Oana Mihaescu ${ }^{\S *}$ and Niklas Rudholm ${ }^{\S}$
}

We use the entry of 17 external shopping malls in Sweden to investigate how they have affected the performance of incumbent firms located in the city centres of small cities. We find that entry by external shopping malls decreased labour productivity for incumbent firms in city centres by $-5.31 \%$. However, when using time-specific fixed effects to control for common time trends in retailing in small cities, the impact on labour productivity, revenues, and number of employees due to the entry of external shopping malls becomes insignificant. The negative impact on incumbent firms is thus not due to the entry of external shopping malls but rather due to longterm negative economic trends in these cities.

Keywords: external shopping malls, city centre, firm performance, agglomeration economies, competition, difference-in-differences.

JEL codes: D22, L25, P25, R12.

\footnotetext{
$\S$ The Institute of Retail Economics, Stockholm, Sweden.

* Corresponding author, e-mail: oana.mihaescu@huiresearch.se.
} 


\section{Introduction}

The retail industry has undergone radical changes since World War II. One of the most debated developments has been the establishment of large external shopping malls outside traditional downtown markets, a trend that has been linked to simultaneous improvements in the road system and consumers' increased access to and use of cars (Forsberg 1998). Meanwhile, the economy has progressively become experience oriented, with the value of consumption being increasingly related to the full consumer experience and not only to purchased goods (Pine and Gilmore 1999; Öner 2014). One consequence is that consumers are willing to travel farther to shop and stay longer on site. Large shopping malls, often located in the outskirts of cities, have the appropriate combination of goods and services to satisfy these needs and have therefore become more attractive as shopping destinations.

The entry of external shopping malls is often claimed to be one cause of the decline of city centres (Stone and McConnon 1982; Monheim 1998; Farhangmehr et al. 2001). However, empirical evidence on the effects of external shopping malls on city centres is inconclusive (e.g., Yalçiner Erkoşkun and Özüduru 2010; Abdelghani 2013), and very few studies have investigated how they affect firms located in smaller cities (Heffner and Twardzik 2015). This is a shortcoming since competition from external shopping malls might act as an incentive for larger cities to redevelop and reinvent their city centres to maintain their attractiveness. Smaller cities, however, have fewer resources, and many of them have experienced negative development during recent decades due to a declining and ageing population. These negative trends occur largely because young people prefer urbanized areas over small cities (Amcoff 2003).

The entry of external shopping malls outside smaller cities implies that incumbent firms in city centres face fiercer competition. It is often argued that external 
shopping malls are winners due to the wider offering of goods and services and higher productivity levels (Freedman and Kosová 2012). The theoretical effects of external shopping malls on incumbent firms in traditional city centres are, however, not exclusively negative. The wider range of a new external shopping mall might attract customers from farther away and result in positive spillover effects for incumbent firms located in city centres (O'Sullivan 2003). The question is whether the positive agglomeration effects can outweigh the combined impact of the negative effects from competition and the long-term negative trends due to declining populations of smaller cities and their attractiveness.

Studies investigating the effects of new shopping malls on the performance of incumbent firms in city centres tend to emphasize the negative effects of increasing competition (e.g., Stone and McConnon 1982; Erkip and Özüduru 2015; Guimarães 2014). Although these studies provide important insights about the intricate relationship between external shopping malls and economic growth in traditional city centres, their results are difficult to generalize outside their original contexts because of methodological limitations. Most papers (e.g., Yalçiner Erkoşkun and Özüduru 2010, Abdelghani 2013; Heffner and Twardzik 2015) are based on case studies that use exclusively interviews and surveys or basic quantitative instruments. In other studies (e.g., Stone and McConnon 1982), survey results are supplemented with regression models at an aggregate level. However, these studies do not allow the accurate identification of any spillover effects on incumbent firms because the data include performance indicators of the new highly productive entrants themselves, leading to an exaggeration of the positive effects (Basker 2007, Rudholm et al. 2018). Another limitation is that the majority of these studies are focused on large cities and metropolitan areas, e.g., New York and Denver in the US (Pratt and Pratt 1960; Lee 
and McCracken 2012), Ankara, Turkey (Özüduru et al. 2014; Erkip and Özüduru 2015), or Brisbane, Australia (Lee and McCracken 2012). We thus lack knowledge of the effects of external shopping malls on incumbent firms in smaller cities, although such firms are potentially more vulnerable to competition from external shopping malls.

We seek to overcome these shortcomings by investigating the effects of external shopping malls on the economic performance of incumbent firms located in the city centres of small cities. To isolate the effects of external shopping malls on the performance of incumbent firms, we consider the entry of external shopping malls as exogenous shocks and apply traditional fixed effect regressions similar to those used in previous studies. We also estimate generalized difference-in-differences regression models to compare the performance of firms entering new areas with their performance before entry and with the performance of firms in small cities without such new external establishments, while controlling for both firm-specific and timespecific heterogeneity. We first investigate the effects of external shopping malls on incumbent firms' labour productivity and next decompose this effect into its effects on real revenues and employment.

When estimating a traditional fixed effects regression model controlling for firm-specific heterogeneity, we find that incumbent firms in the city centres experienced a productivity loss of $-5.31 \%$ when external shopping malls entered the outskirts of the small city. However, many small cities have experienced declining and ageing populations. To account for such negative trends, we also add time-specific fixed effects to the regression specification and estimate what amounts to a generalized difference-in-differences model. We find that all effects of external shopping malls on the performance of incumbent firms in city centres then become insignificant. Our results thus suggest that incumbent firms in small cities have a negative development 
path mainly due to long-term economic trends, possibly because of the corroboration of urbanization effects and a lack of local investments, not because external shopping malls have entered areas outside these cities.

In the next section, we discuss the role of firm location in economic geography. In section 3, we present previous studies about the effects of large investments in external shopping malls on the development of traditional city centre trade. Section 4 is dedicated to a description of the data and the empirical method. In section 5 , we present and discuss the results, while section 6 concludes the study.

\section{Firm location in economic geography}

The relationship between two markets is intricate and depends on their threshold and range, the physical distance between them, and the available customer base in the region. In line with central place theory (Christaller 1933), the threshold is the minimum population (or income) needed to support the commercialization of a product or service. The range is the maximum distance consumers are prepared to travel to acquire a good or service.

Assuming a monocentric city, the establishment of an external shopping mall often generates a situation where the external and central markets coexist. If the physical distance between the two markets is larger than the sum of their ranges (i.e., their ranges do not overlap geographically), then the likelihood of the two markets having a significant impact on each other is low. However, in the case of small cities, the ranges of the two centres likely overlap, which may generate a competitive situation. External shopping malls are often larger and sell a wider range of high-order goods (i.e., durable goods), thus exhibiting larger ranges than small city centres. Consequently, customers are willing to travel to the new external shopping malls from 
farther away, suggesting that these external shopping malls may acquire a share of the customers who typically used to patronize the city centre. This situation can generate increased sales for firms in external shopping malls at the expense of firm sales in traditional city centres.

This kind of market dynamic is more likely to be observed in smaller cities with an often decreasing or stagnating population. While large cities with growing populations may be able to supply the required customer threshold both for new external shopping malls and for the old markets located in the city centres, the customer base in smaller cities is often not sufficient to support both markets (Freedman and Kosová 2012). Furthermore, strong urbanization trends have made many small cities experience declining or stagnating population trends compared to the trends of their larger counterparts (SCB 2020).

In Sweden, cities with less than 10 ooo inhabitants increased their population by an average of $0.34 \%$ yearly between 2000 and 2017 , while the population in cities with $10000-25$ ooo inhabitants increased yearly by $0.47 \%$ on average, and the population in cities larger than 25000 inhabitants increased by $1.22 \%$ on average. The population of the three main metropolitan areas, Stockholm, Gothenburg, and Malmö, increased by $1.53 \%$ on average during the same time period. ${ }^{1}$ If the customer base in a region is small, the most attractive retail cluster with a competitive advantage over the neighbouring shopping malls will 'win' the customers. Thus, the establishment of an

\footnotetext{
${ }^{1}$ Although the population growth levels differ considerably between different categories of cities in Sweden, the fact that we mainly observe positive population trends regardless of city type and size is explained by an influx of immigrants from mainly Middle East countries affected by war, in particular from Syria. Almost 1.8 million immigrants entered Sweden in the period 2000-2017, and the Swedish population was 10.3 million in 2019 (SCB 2020).
} 
external shopping mall may claim, in small monocentric cities, much of the city centre's old customer base and may thus increase the likelihood that city centres in small cities experience a decrease in demand following the entry of external shopping malls.

With the problem generated by a low customer base, the response of the city centres to increased competition depends on their capacity to win back some of their old customers and attract new ones and thus increase their economic performance or, in other words, increase output (i.e., revenue) for the same (or lower) input (i.e., employment). This requires some amount of innovation (Porter 1990), as firms in city centres are compelled to, for example, differentiate their products from those of their external competitors to limit competition and ensure resilience (Picone et al. 2008). However, incumbents that do not react appropriately may experience a decrease in revenue when an external mall enters and may likely eventually be displaced from the market. $^{2}$

The possible effects of investments in external shopping malls on local incumbents are, however, not exclusively negative. The wider range of a new external shopping mall is likely to attract an increased customer base that may to some extent spill over to the other firms in the region, including city centre incumbents. These potential positive effects generated by the proximity of the two markets are known as agglomeration externalities. The functional mechanism of agglomeration externalities is based on economies of scale that occur when the sales of one firm increase or when

\footnotetext{
${ }^{2}$ Our dataset is not ideally suited for identifying entry and exit. The only way to identify entry and exit is by recording when a specific organization number for a retail firm appears in or leaves the dataset. There can, however, be a number of reasons for this other than the formal entry or exit of a retail firm. If, for example, a firm is sold, it is often but not always the case that the firm is registered with a new organization number. Thus, we are unable to analyse the effects of new shopping malls on firm entry and exit in the entry regions.
} 
production costs decrease because of firm co-location (O'Sullivan 2003). Agglomeration externalities can occur in the form of both demand and supply spillovers.

Demand spillovers are specific to consumer-oriented industries such as retail, the hotel and restaurant industry, and commercial service, and such spillovers occur when the sales of one firm are affected by the location of other firms commercializing either imperfect substitutes or complements. The co-location of firms selling imperfect substitutes provides the basis for comparison shopping, while the co-location of firms selling complements allows for multipurpose shopping. Comparison and multipurpose shopping help minimize consumer search costs and maximize consumer utility (van Handel 1970; Wolinsky 1983; Brown 1989), contributing to the attractiveness of the region and generating a customer flow between the new external shopping mall and the traditional central market. As explained by Marshall's (1890) theory of agglomeration economies, the co-location of firms also generates supply spillovers in the form of decreased input costs, a local skilled labour pool that facilitates a more efficient labour matching process, and increased knowledge spillovers in the region (McCann 2001; O’Sullivan 2003). Spillovers may be industry-specific (so-called localization or specialization externalities) (Marshall 1920), or may occur between complementary industries (so-called urbanization or diversification externalities) (Jacobs 1969), or both. 


\section{External shopping malls and high street shopping: previous}

\section{research}

How are incumbent firms in the city centres of small cities impacted by the entry of external shopping malls? Do negative competition forces or positive agglomeration spillovers dominate when external shopping malls enter in the outskirts of small cities? An investigation of the previous studies in the field shows that the answer is not straightforward.

The establishment of an external shopping area often includes entry by at least one large anchor store, and several studies have attempted to investigate how these big-box stores affect the markets they enter. Such large retailers are likely to display high levels of labour productivity (Foster et al. 2006). According to Basker (2007), Wal-Mart's real value added per worker was $40 \%$ higher than that of other general merchandise retailers, and its productivity increased by $55 \%$ over the $1982-2002$ period. Entry by these retail giants in local markets is thus likely to displace less productive local retailers. Jia (2008) reported that Wal-Mart entry caused $50-70 \%$ of the net exits of small discount retailers in the US market and that the exiting establishments were $25 \%$ less productive than the surviving incumbents.

This negative effect on labour productivity seems to be due to competition forces that induce a decrease in sales for incumbent firms. Singh et al. (2006) found that incumbent supermarkets lost $17 \%$ of sales volume due to customer migration to new Wal-Mart stores. This result was later supported by Ailawadi et al. (2010), who identified significant sales losses for incumbent firms as a result of Wal-Mart entering the market but found substantial variation across retail formats, stores, and product categories. Competition effects seem to prevail over any agglomeration effects, particularly in situations where incumbent stores located in the entry cluster sell 
substitutes for the items carried by the new big-box entrants (Zhu et al. 2011; Han et al. 2018; Daunfeldt et al. 2019). Furthermore, both Ellickson and Grieco (2013) and Arcidiacono et al. (2020) observed that these competitive effects generated by the establishment of new Wal-Mart stores decayed with distance from the entry location.

The decrease in sales, however, seems to be followed by quick adjustments in employment in certain contexts. For example, Haltiwanger et al. (2010) identified negative effects of a big-box store on employment at single-unit and smaller chain stores located in the immediate area and operating in the same industry as the large entrant. However, employment levels do not always follow revenue changes. Jones and Doucet (2000) found increasing proportions of retail employment within $2 \mathrm{~km}$ of a new big-box store, and Daunfeldt et al. (2019) found that incumbents located near IKEA stores experienced increasing revenue levels due to positive spillover effects, while the effects on employment were negligible.

It is, however, hard to generalize these results to our setting because they focus on the entry of a large big-box entrant (often Wal-Mart) in a shopping area, while our study instead focuses on the effects of the establishment of the whole external shopping mall. External shopping malls in small cities in Sweden also tend to differ from those in larger cities because they seldom include one dominant store, such as IKEA. Instead, they often include a number of medium-sized establishments.

Early studies that focused on the impact of external shopping malls on incumbent retailers emphasized the negative competition effect (see Table 1). For example, Pratt and Pratt (1960) used interviews to identify changes in customer behaviour generated by the establishment of suburban shopping malls, observing a shift in the demand of suburban consumers from the central city to these new suburban shopping malls. They identified a net decrease of $54 \%$ in the number of customers of 
incumbents located in the central city (New York) but also a 22\% decrease in the number of customers of incumbent stores located in the suburban city centres.

Stone and McConnon (1982) summarized survey results and outcomes of county-level econometric studies and concluded that one-quarter to one-third of the merchants located in the entry areas perceived the new shopping malls to have a negative impact on their businesses. More recent studies have also emphasized competition over agglomeration effects. 3 Howard and Davies (1993) used surveys complemented by pedestrian counts, vacancy statistics, and changes in land use patterns to assess the 'health' of traditional shopping streets. The surveyed shop owners acknowledged decreases in both sales and employment following the entry of external shopping malls. Other authors noted that many of these stores exited the market because they were unable to compete with the new malls (Monheim 1998; Farhangmehr et al. 2001).

As in the case of big-box entry, the negative effects of external shopping malls are heterogeneous and depend on both the retail mix and the distance to the incumbent stores (Howard and Davies 1993). Traditional markets may thus continue to attract customers in search of certain types of goods that are complementary to large shopping malls, such as non-chain clothing and traditional local foods, and particularly to attract high-income earners who are searching for variety and uniqueness in retail goods and

\footnotetext{
3 Several other papers that focused on the relationship between shopping malls and incumbent businesses are beyond the scope of our study. For example, Dart (1988) investigated small retailers that relocate to the new shopping malls. Maronick and Stiff (1985), Whysall (1995; 2011), Lowe (2005a,b), and Maronick (2007) investigated entry by large city centre stores and shopping malls as retail-led urban regeneration strategies in response to the problems associated with the proliferation of external shopping malls. Chen et al. (2010) proposed a method to determine the optimal location choice for new shopping malls based on their possible impacts. In addition, Delic and Knezevic (2014) carried out a comparative description of the development of shopping malls in Southeast European countries.
} 
services. Incumbent firms developing innovative strategies and differentiating their offers from those of external shopping malls may thus be more resilient (Erkip and Özüduru 2015). Such positive reactions have been observed particularly in large cities with increasing population and disposable income (Glaeser 2011; Erkip and Özüduru 2015), suggesting that a sufficiently large customer base and the availability of resources for innovation and of entrepreneurial capacity are essential for the financial profitability of high-street incumbents.

Although these studies provide important insights about the relationship between external shopping malls and economic outcomes in traditional city centres, their results are difficult to generalize outside their original contexts because of several methodological limitations. First, several papers are based on case studies that use exclusively qualitative research methods or descriptive statistics (e.g., Yalçiner Erkoşkun and Özüduru 2010) and basic quantitative instruments. For example, Abdelghani's (2013) study is solely based on surveys and interviews with shop owners. Stone and McConnon (1982) used surveys and supplemented them with regression models at an aggregate level. However, the use of aggregate data does not allow the accurate identification of any spillover effects on incumbent firms because the data include the performance indicators of the new entrants themselves. These new shopping malls often exhibit high sales levels and are highly productive, and averaging over all firms, both new and incumbents, most likely leads to an exaggeration of the positive effects for incumbent retailers (Basker 2007; Rudholm et al. 2018).

Another limitation originates in the geographical restrictions applied in these studies. Several of them are focused on large cities and metropolitan areas, e.g., New York and Denver (the US), Ankara (Turkey), or Brisbane (Australia). The viability of these city centres is sustained by large populations and high income levels. Smaller cities are, however, more likely to be vulnerable to investments in external shopping 
malls. Nonetheless, the effects of shopping malls on incumbent firms in small cities have received scarce attention in the literature. Heffner and Twardzik (2015) attempted to discuss the impacts of shopping malls in smaller towns and rural areas, but their study was exclusively based on interviews with local authorities. The collected answers indicated a generalized perception that the entry of shopping malls leads to an outflow of customers from smaller shops and a decline in door-to-door trading, street trading, and traditional retail shops. They also observed that while the retail structure has not changed considerably in rural municipalities, where the small shops dominate, small but non-rural municipalities experienced an expansion of small supermarkets.

Previous studies often do not either control for essential factors, such as trends in the output variable (e.g., Stone and McConnon 1982), when investigating the effect of large retail establishments on the performance of incumbent firms. Rodrígues-Pose (2018) argued that smaller places and rural areas for a long time have been regarded as 'places that do not matter', characterized by economic decline and lack of opportunities and consequently of investments. Not accounting for such trends means that a negative effect on incumbent retailers due to long-term socio-economic or demographic trends in the entry cities might be mistakenly identified as an effect of new external shopping malls. Trends are important to consider when investigating spillover effects in smaller cities because wages have persistently lagged in these cities compared with their larger urban counterparts (Henderson et al. 2001; Rice et al. 2006) due to a gap in productivity between urban and rural areas that is inherently linked to firm productivity (Saito and Gopinath 2009).

Among previous studies that accounted for negative time trends, Artz and Stone (2012) identified a negative impact of Wal-Mart supercentres that is limited to larger competitive supermarkets, concluding that these Wal-Mart giants do not hurt locally owned subsidiary business establishments. This result is also confirmed by Hicks et al. 
(2012). In addition, when investigating the effects of IKEA shopping malls, Daunfeldt et al. (2019) found no statistically significant effect on the performance of incumbent retailers located in city centres. Arcidiacono et al. (2020) also corrected for trends in their models, finding negative effects on incumbent firms' revenues that quickly decline with distance from new Wal-Mart stores (from $12 \%$ at $1.6 \mathrm{~km}$ (1 mile) to $5 \%$ at 4.8-8 $\mathrm{km}(3-5$ miles)) and become insignificant for distances greater than $8 \mathrm{~km}$ (5 miles). Ellickson and Grieco (2013) reported similar results with respect to the effects of Wal-Mart entry on employment. While providing examples of robust statistical analysis, the only one of these studies that investigates the effects of external shopping malls on the performance of city centre firms is Daunfeldt et al. (2019), and none is explicitly focused on the impact on the performance of firms located in small cities.

To summarize, the results from previous studies are far from conclusive, and there is a lack of studies that use estimation techniques to account for time-specific heterogeneity. There is also a dearth of studies investigating the effects of external shopping malls on incumbent firms in small cities. We overcome these shortcomings by using the entry of external shopping malls in small cities as a natural experiment and by applying regression techniques in a difference-in-differences setting to investigate how the entry of external shopping malls affects the performance of incumbent firms located in city centres. To investigate whether long-term economic trends in these small cities could potentially confound the estimation of the effects of external shopping mall entry on incumbent city centre firms, we present and discuss results from a model both with and without controls for time trends. 
Table 1. Previous studies on the impact of external shopping malls on city centres

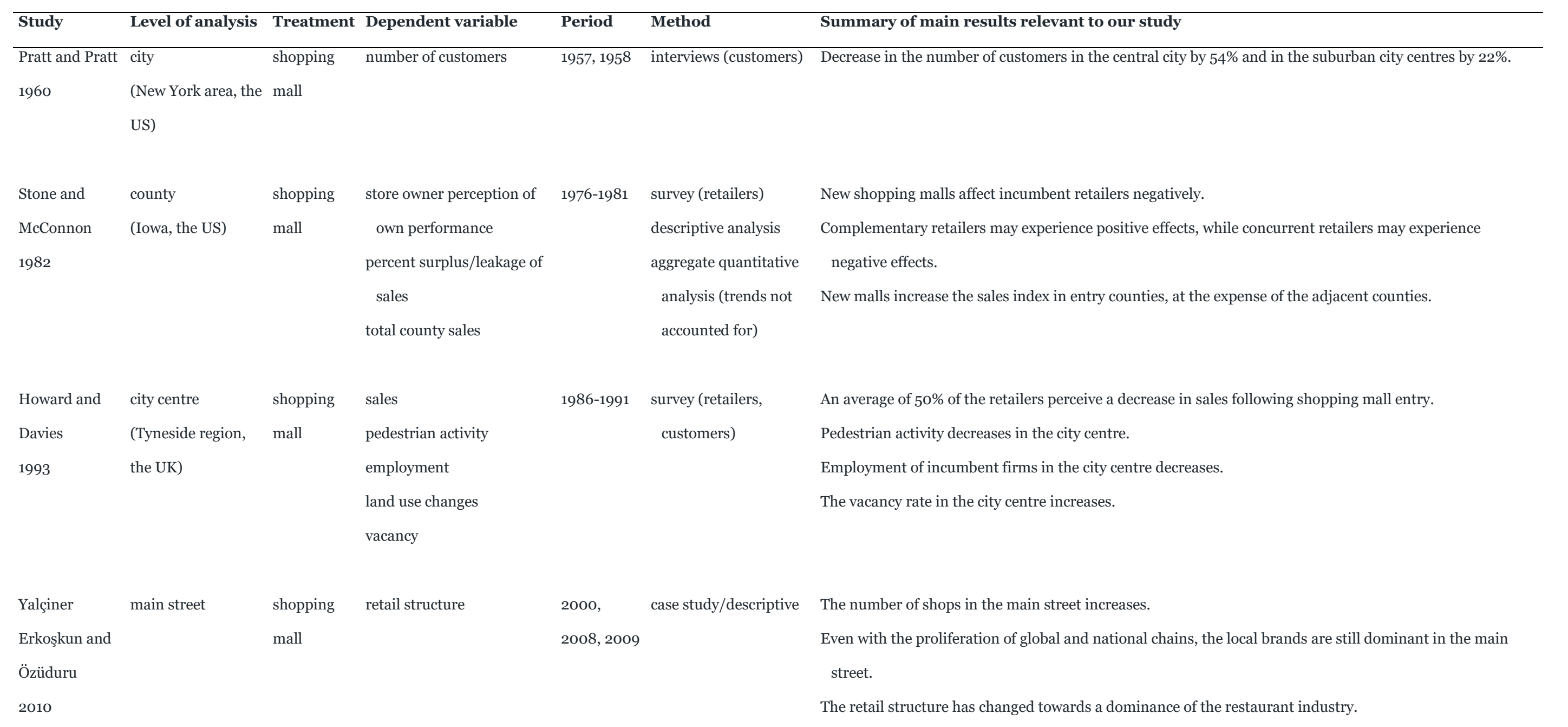




\begin{tabular}{|c|c|c|c|c|c|}
\hline Lee and & city & shopping & retail structure & 2010 & descriptive analysi \\
\hline McCracken & (Denver, USA and & mall & & & correlation analy \\
\hline \multirow[t]{2}{*}{2012} & Brisbane, & & & & \\
\hline & Australia) & & & & \\
\hline Abdelghani & city centre & shopping & retail structure & 2009-2010 & survey (customers \\
\hline \multirow[t]{2}{*}{2013} & (Muscat region, & mall & & & interviews (custom \\
\hline & Oman) & & & & \\
\hline Özüduru et al. & city centre & shopping & consumer profiles & 2010 & survey (customers \\
\hline \multirow[t]{3}{*}{2014} & shopping street & mall & consumer preferences & & \\
\hline & (Ankara, Turkey) & & consumer spatial & & \\
\hline & & & behaviours & & \\
\hline Erkip and & firm & shopping & store owner perception of & 2011, 2013 & survey (retailers) \\
\hline Özüduru & (Ankara, Turkey) & mall & own performance & & \\
\hline 2015 & & & land use changes & & \\
\hline
\end{tabular}

Retail abandonment has been observed in Denver following the process of suburbanization of both housing and retail. Brisbane, on the other hand, has been able to preserve the Central Business District as its major retail area in the city. This is mainly due to differences in public policy and ownership patterns in the two cities.

Shopping malls have a negative impact on traditional markets in certain retail subsectors, such as clothing and cosmetics.

The traditional market is, however, maintaining its attractiveness in regard to local and traditional goods (clothing and food) and as a social meeting place.

Shopping malls are preferred by older, better-educated, car-owning households with children living in

suburban areas. Shopping streets are preferred by the younger population - singles without children and students.

Shopping malls are preferred for shopping, strolling, eating, and drinking. Shopping streets are preferred in particular for socializing, entertainment, and strolling.

Shopping malls are patronized by customers from the whole city. Shopping streets are preferred by customers from the surrounding neighbourhoods.

Shopping street retailers complain about shopping mall competition.

However, land use analysis indicates that firms in city centres are resilient. This is due to, on one side, firms developing resilience strategies and a complementary offer and, on the other side, increased population and income levels in the region. 


\begin{tabular}{|c|c|c|c|c|c|c|}
\hline Guimarães & city & shopping & shopping behaviour & 2009 & survey (consumers) & Of the residents, $46 \%$ admitted to a possible transfer of shopping to external shopping malls. This is \\
\hline 2014 & (Braga, Portugal) & malls & & & & $\begin{array}{l}\text { expected to lead to a decrease in the vitality and viability of the city centres but also to reactive measures } \\
\text { in the city centres. }\end{array}$ \\
\hline $\begin{array}{l}\text { Heffner and } \\
\text { Twardzik } \\
2015\end{array}$ & $\begin{array}{l}\text { municipality } \\
\text { (Silesia region, } \\
\text { Poland) }\end{array}$ & $\begin{array}{l}\text { shopping } \\
\text { malls }\end{array}$ & retail structure & 2013 & $\begin{array}{l}\text { interviews (municipal } \\
\text { authorities) }\end{array}$ & $\begin{array}{l}\text { There is a generalized perception that the entry of shopping malls leads to an outflow of customers from the } \\
\text { smaller shops towards external shopping malls. An expansion of small supermarkets is observed, however, } \\
\text { in small non-rural municipalities. A decline in door-to-door trading, street trading, and traditional shops } \\
\text { (e.g., blacksmith shops) is also noted. However, the retail structure has not changed considerably in rural } \\
\text { municipalities, where the small shops continue to dominate. }\end{array}$ \\
\hline $\begin{array}{l}\text { Daunfeldt et } \\
\text { al. } 2019\end{array}$ & $\begin{array}{l}\text { firm } \\
\text { (Sweden) }\end{array}$ & $\begin{array}{l}\text { IKEA retail } \\
\text { areas }\end{array}$ & $\begin{array}{l}\text { firm revenue } \\
\text { firm employment }\end{array}$ & 2000-2010 & $\begin{array}{l}\text { difference-in- } \\
\text { differences (trends } \\
\text { accounted for) }\end{array}$ & $\begin{array}{l}\text { Revenues for incumbent retailers located } 1 \mathrm{~km} \text { from a new IKEA retail area experienced a } 7 \% \text { increase due } \\
\text { to positive spillover. The effect was insignificant for firms located less than } 1 \mathrm{~km} \text { from a new IKEA retail } \\
\text { area or in city centres. The positive effects dominate negative effects from competition only for firms } \\
\text { selling complements to IKEA, while substitute firms located } 2-5 \mathrm{~km} \text { from the new retail area experience } \\
\text { revenue loss due to IKEA entry. The effects on employment are statistically insignificant. }\end{array}$ \\
\hline
\end{tabular}




\section{Data and descriptive statistics}

\subsection{The city centre}

In line with the morphological classification of cities described in the European Union's ESPON programme4, we define cities with a population of 5 Ooo-25 000 inhabitants and a population density of more than 300 inhabitants per squared kilometre as small cities (ESPON 2014). We then define the geographical scope of these city centres based on a combination of population density and firm density, taking into consideration geospatial barriers. The limits of the city centre are established based on 250 x 250metre geographical quadrants defined by Statistics Sweden. A quadrant is part of the city centre if its density corresponds to minimum levels in terms of both population and the number of firm establishments. The minimum levels vary with the size of the total city population and are, on average, equal to 219 residents and 13 firms per geographical quadrant.5

The requirements for meeting minimum levels for both population density and store density mean that areas with sole functions, such as residential neighbourhoods or external shopping malls, cannot be defined as city centres. Furthermore, no cities with fewer than 10 ooo inhabitants fulfil the simultaneous minimum requirement for population and firm density, and these cities are consequently excluded from our analysis. Of the 76 cities with more than 10000 inhabitants that are defined as small, eight cities do not have a city centre according to the definition above. This leaves us

\footnotetext{
4 For more information, visit https://www.espon.eu/topics-policy.

5 The minimum levels for each city are the result of a workshop with representatives of academic institutions, industry associations, city officials, property owners, consulting companies, retailers, and the hospitality industry.
} 
with a sample of 68 small cities, of which 17 experienced entry of a new external shopping mall during our period of analysis (2000-2016). ${ }^{6}$

\subsection{External retail}

Following the definition used by the Nordic Council of Shopping Centers (NCSC 2017), we classify shopping malls into the following nine categories according to their gross leasing area (GLA), number of tenants, and location: city malls, neighbourhood centres, community centres, outlet centres, theme centres, regional malls, retail parks, regional retail parks, and super-regional malls. The external shopping malls located in the small cities included in our study fall into four of these categories, namely, city malls, neighbourhood centres, community centres, and retail parks. City malls are located in city centres, and neighbourhood and community centres are small and located in predominantly residential neighbourhoods. We therefore focus our study on the 17 retail parks7 that were established during the period 2000-2016. The smallest retail area in our sample has a GLA of 7600 sqm (approximately 82 ooo sq ft), and the

${ }^{6}$ Two different external shopping malls have been established in Norrtälje during our study period. As we want to identify what happens when a small city that previously did not have access to external shopping acquires one, we focus solely on the first entry (Knutby Torg, established in 2005) in our statistical analysis. Notably, the second entry (Flygfältets Handelsområdet, 2012) was both considerably smaller and entered quite late in our study period, thus making it unlikely that we could identify any additional effects of that entry in our statistical analysis.

7 A precise entry year is not indicated in the original database for five other retail parks that were established in some of our analysed cities. After contact with city officials, we found that these shopping malls were established long before the start of our study period and would thus not be included in our treatment group. Two more centres entered in 1990 and 1995 and thus were not included in the treatment group in our study either. Following Daunfeldt et al. (2019), we assume that the entry areas arrived at a new equilibrium level of sales after every entry. Older entries therefore should not cause any trends in the key variables that could potentially confound the identification of the impact of external shopping on incumbents in the city centres during the study period. 
largest has a GLA of 40475 sqm (approximately $436000 \mathrm{sq} \mathrm{ft}$ ), with an average of 20 674 sqm (approximately 222500 sq ft); see Table 2.

Table 2. External shopping malls that opened between 2000 and 2016 in small cities with 10 000-25 000 inhabitants in Sweden.

\begin{tabular}{llll}
\hline City & Shopping mall & Entry & GLA 2016 \\
& & year & (sqm) \\
\hline Sandviken & Mosaiken Handelsområde & 2002 & 14800 \\
Norrtälje & Knutby Torg & 2005 & 38050 \\
Stenungsund & Strandplan & 2005 & 23000 \\
Katrineholm & Lövåsens Handelsområde & 2006 & 36875 \\
Strängnäs & Solberga Köpcenter & 2007 & 21200 \\
Mora & Noret Köpcentrum & 2007 & 40475 \\
Visby & Handelsplats Stenhuggaren & 2008 & 18950 \\
Falköping & Ålleberg Center & 2008 & 19350 \\
Staffanstorp & Rondellen, Staffanstorp & 2008 & 15000 \\
Ludvika & Lyviksberget & 2008 & 22400 \\
Ljungby & Ljungbyporten & 2009 & 12350 \\
Gällivare & Malmhedens Handelsområde & 2011 & 20100 \\
Gislaved & Smålandia Köpcentrum & 2011 & 7600 \\
Lidköping & Änghagens Handelsplats & 2012 & 18000 \\
Västervik & Ljunghedens Handelsområde & 2012 & 21550 \\
Härnösand & Handelsområde Ankaret & 2012 & 15975 \\
Vetlanda & Nydala Handelsområde & 2014 & 9500 \\
\hline & & & \\
\hline
\end{tabular}

An example of the typical location of these external shopping malls in relation to the city centres in these small cities is illustrated in Figure 1. 


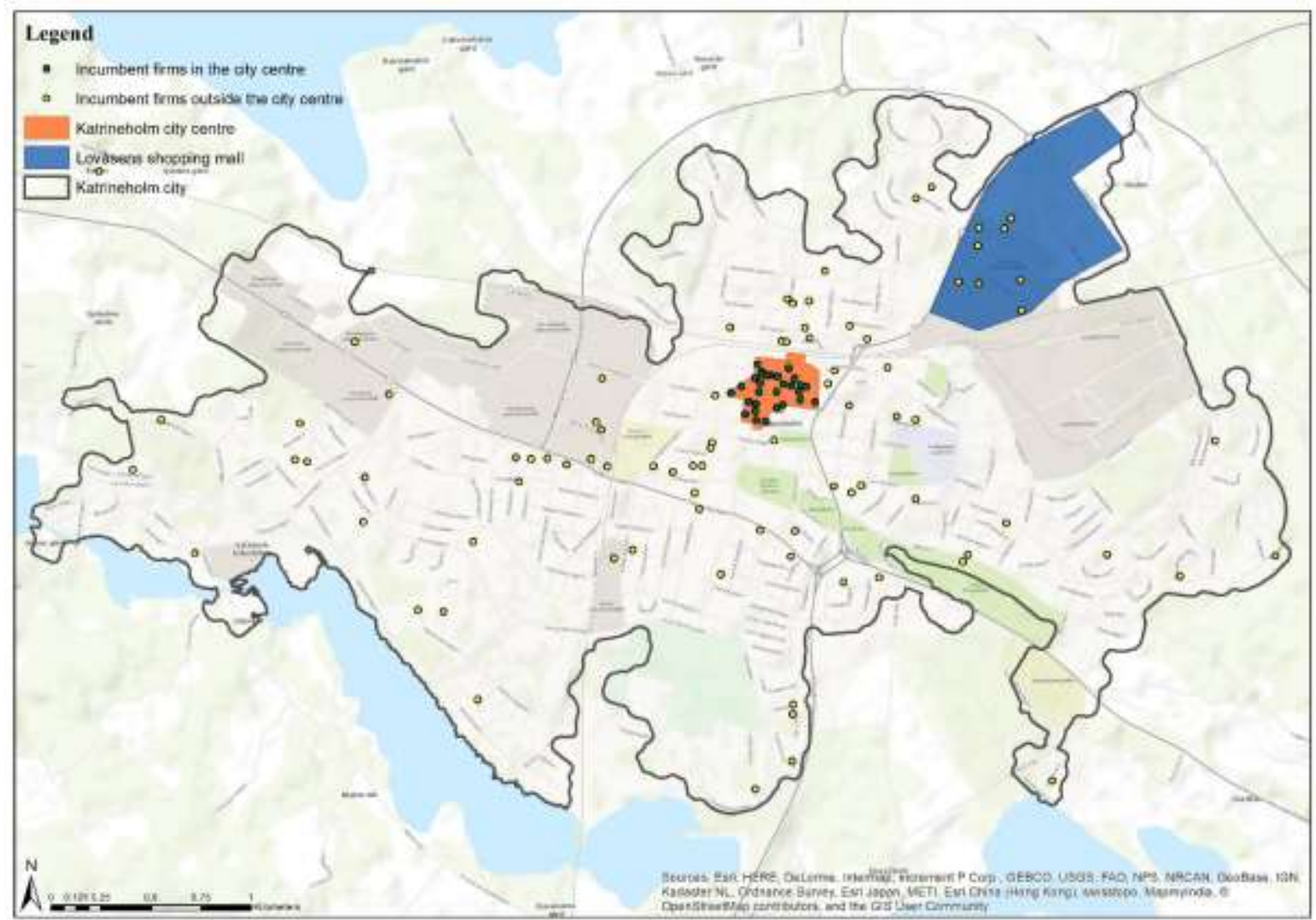

Figure 1. The city of Katrineholm with its city centre and Lövåsens retail park

\subsection{Descriptive statistics for the outcome variables}

All limited liability firms in Sweden are required by law to submit their annual reports to the Swedish Patent and Registration Office (PRV). We use a dataset from Bisnode, a consulting company that compiles this information from PRV. All data in the annual reports are included, such as revenues, number of employees, location and industry classification. ${ }^{8}$ Our main dataset covers 2506 firms active for at least one year during the 2000-2016 period in the city centres of the 68 small cities included in our study, yielding an unbalanced panel of 20221 firm-year observations.

\footnotetext{
${ }^{8}$ As we link firm performance indicators to firm location, we are compelled to restrict our study to firms reporting performance indicators at the establishment level and exclude multi-establishment firms only reporting performance indicators at the headquarters level. However, our data show that approximately $90 \%$ of all firms in our sample are single-establishment firms.
} 
We seek to investigate how the entry of external shopping malls in these small cities affects the performance of firms located in city centres. Following Özçelik (2020), we measure firm performance by labour productivity and decompose this measure into real revenues and number of employees. Descriptive statistics for the first and last years of the analysis are presented in Table 3 for incumbent firms located in the city centres. We discount firm revenues by the Swedish consumer price index (CPI), and the number of employees is adjusted by adding one because the only 'employed' person is often the owner and many firms thus record zero employees.

Table 3. Descriptive statistics for the variables in our study (for city centre incumbents), 2000 and 2016

\begin{tabular}{|c|c|c|c|c|c|c|}
\hline & 2000 & & & 2016 & & \\
\hline Variable & Mean & Std. dev. & $\mathbf{N a}^{\mathrm{a}}$ & Mean & Std. dev. & $\mathbf{N}^{\mathrm{a}}$ \\
\hline $\begin{array}{l}\text { labour productivity } \\
\text { (1 ooo SEK) }\end{array}$ & 1015.6 & 783.1 & 1080 & 965.5 & 997.6 & 1235 \\
\hline $\begin{array}{l}\text { real revenue } \\
\text { (1 ooo } \mathrm{SEK})\end{array}$ & 5548.4 & 9733.8 & 1091 & 5562.6 & 11019.2 & 1276 \\
\hline $\begin{array}{l}\text { employment } \\
\text { (number of employees) }\end{array}$ & 4.78 & 4.27 & 1080 & 5.13 & 4.50 & 1235 \\
\hline
\end{tabular}

a Number of observations (N) differs slightly when computing statistics for labour productivity and for employment, on the one hand, and for real revenue, on the other, because some firms have reported revenues but did not report the number of employees.

The data show that labour productivity has decreased somewhat during the study period regardless of whether the city has an external shopping mall or not. However, Table 4 shows that the decrease in productivity is more accentuated in small cities with external shopping malls (-7.53\%) than in small cities without external shopping malls (-3.55\%). When decomposing labour productivity into real revenues 
and employment, we observe that the average revenue of firms in the city centres remains relatively constant, while the number of employees is growing. The data indicate a change of only $0.26 \%$ in the average firm real revenue between 2000 and 2016 and a considerably larger change in employment at $7.32 \%$. In city centres without external shopping malls, both revenues and the number of employees increase, but the increase in real revenue (7.96\%) is superseded by the increase in employment (11.69\%). Revenues for firms in the city centres of small cities with external shopping malls, however, decrease by $-12.11 \%$, while the employment numbers indicate no change ($0.20 \%)$.

Table 4. Percent change in average labour productivity, real revenues, and employment for city centre incumbents, 2000-2016

\begin{tabular}{|c|c|c|c|c|c|c|c|c|c|}
\hline \multirow[b]{2}{*}{ City centres } & \multicolumn{3}{|c|}{ Labour productivity } & \multicolumn{2}{|c|}{ Real revenues } & \multicolumn{4}{|c|}{ Employment } \\
\hline & 2000 & 2016 & $\begin{array}{l}\text { \% } \\
\text { change }\end{array}$ & 2000 & 2016 & $\begin{array}{l}\% \\
\text { change }\end{array}$ & 2000 & 2016 & $\begin{array}{l}\text { \% } \\
\text { change }\end{array}$ \\
\hline all & $1015 \cdot 7$ & 965.50 & -4.94 & 5548.4 & 5562.6 & 0.26 & 4.78 & 5.13 & $7 \cdot 32$ \\
\hline $\begin{array}{l}\text { with external } \\
\text { shopping malls }\end{array}$ & 1058.7 & 979.00 & -7.53 & 5968.3 & $5245 \cdot 5$ & -12.11 & 5.09 & 5.08 & $-0.2 O$ \\
\hline $\begin{array}{l}\text { without external } \\
\text { shopping malls }\end{array}$ & 992.91 & 957.63 & -3.55 & 5324.9 & 5748.8 & 7.96 & 4.62 & 5.16 & 11.69 \\
\hline
\end{tabular}

The question is how many of these changes are due to the entry of the new external shopping areas? While giving us interesting information, these comparisons of how the outcome variables have changed from 2000 to 2016 cannot isolate the entry effect from the possible effects of other events and of local, regional, and national economic trends. In the next section, we attempt to isolate the entry effects of external shopping malls from these other factors by means of a difference-in-differences type of regression model. 


\subsection{Model identification}

We use entry by new external shopping malls as a natural experiment to investigate how such entry affects incumbent firms located in the city centres of small cities. The main identification problem is that firms located in city centres cannot be observed in the counterfactual state when no large external shopping centre enters the market. In addition, as noted by Greenstone et al. (2010), firms tend to choose locations that maximize their profits, implying that the entry cities differ from randomly selected cities. If we want to measure how new external shopping malls affect incumbent firms in the inner cities, we thus need to identify a set of control cities that are as identical as possible to the entry cities.

In line with Hotelling's (1929) spatial differentiation theory, the size and offer of a retail site determines its market area and therefore the number of consumers who are willing to travel to the site for shopping, which is key to reaching a profitable sales level (e.g., Ghosh and McLafferty 1987; Gonzalez-Benito and Gonzalez-Benito 2005; Lee and Kim 2018). Retail sites of different sizes (and thereby offers) may thus substantially differ from each other and from random cities in Sweden. By restricting our sample to small cities with $10000-25000$ inhabitants, where the potential customer base is limited, we inherently focus on a group of cities with similar purchasing power. More than $70 \%$ of these cities show negative or low positive population growth trends, and they are also geographically similar, with monocentric urban structures focused around a small traditional core.

To determine the effect of new external shopping malls on the performance of city centre firms, we depart from the general setup as illustrated in equation (1).

$$
\ln Y_{i t}=\beta_{0}+\beta_{\mathrm{TR}} \times T R_{i t}+u_{i t},(1)
$$


where $Y_{i t}$ is labour productivity, measured as the real revenues per employee and evaluated annually at the firm level for all firms in the city centres. The treatment variable, $T R_{i t}$, is equal to one after the entry year for firms located in cities that have experienced the entry of external shopping malls in the study period and zero before the entry year for firms in cities with external shopping malls and for firms in cities that have not experienced the entry of an external shopping mall during the study period.

The model specification above allows us to compare firms in the treatment group (i.e., firms located in small cities with entry of external shopping malls) to firms in the control group (i.e., cities with external shopping malls, before entry, and cities without entry of external shopping malls). The hypothesis to be tested is whether the development of labour productivity differs significantly between the two groups of firms (treated and control), which would be indicated by a statistically significant coefficient $\beta_{\mathrm{TR}}$. The identification of the $\beta_{\mathrm{TR}}$ coefficient may, however, be confounded by a potential correlation between the treatment variable $\left(T R_{i t}\right)$ and the error term $u_{i t}$, for example, due to omitted variables. To address this issue, we follow Arcidiacono et al. (2019) and include firm-specific fixed effects to account for time-invariant heterogeneity at the firm level.

However, even after the inclusion of firm-specific fixed effects, remaining heterogeneity related to time-varying trends common to small cities may further impair the correct identification of the $\beta_{\mathrm{TR}}$ coefficient. If we do not account for such time trends, we might confound the effects of long-lasting trends in small cities with the entry effects of external shopping malls. Consequently, for the correct identification of the $\beta_{\mathrm{TR}}$ coefficient, we need to specify $u_{i t}$ as a function of firm-fixed effects, $\gamma_{i}$, timespecific fixed effects, $\vartheta_{t}$, and a residual error term, $\varepsilon_{i t} \sim i i d N\left(0, \sigma_{\varepsilon}^{2}\right)$. 


$$
u_{i t}=\gamma_{i}+\vartheta_{t}+\varepsilon_{i t}
$$

Consequently, our most general model can be written as a generalized difference-in-differences specification:

$$
\ln Y_{i t}=\beta_{0}+\beta_{\mathrm{TR}} \times T R_{i t}+\gamma_{i}+\vartheta_{t}+\varepsilon_{i t} .
$$

Our identifying assumption is thus that the timing and location of new external shopping malls is uncorrelated with $\varepsilon_{i t}$, conditional on the firm- and time-specific fixed effects. Finally, note that the $\log$ transformation of the outcome variable $\left(\ln Y_{i t}\right)$ has the benefit of making the parameter estimate related to the effect of entry on incumbentstore labour productivity interpretable in percentage terms after using the formula $100 \times\left[\exp \left(\beta_{\mathrm{TR}}\right)-1\right]($ Wooldridge 2010).

\section{Results}

\subsection{Effects of external retail on city centre incumbents}

We start by estimating a model with firm-specific fixed effects (Model 1) and then add time-specific fixed effects (Model 2), as suggested in previous research (e.g., Drewianka and Johnson 2006; Newmark et al. 2008; Artz and Stone 2012). Model 2 is our most general model and controls for firm-level time-invariant heterogeneity among firms in the treatment and control groups but also for common trends in labour productivity for firms located in the city centres of small cities.

The estimated average effects of external shopping malls on the labour productivity of incumbent firms located in small city centres are presented in Table 5 . The results from Model 1 indicate a negative and statistically significant effect of external shopping malls in small cities on the labour productivity of firms in the city centres when ignoring the possibility of long-term trends affecting the results. 
According to the results, labour productivity declines on average by $-5.31 \%$ for firms located in city centres when external shopping malls enter these small cities. Revenues decrease by $-6.62 \%$, while the reduction in the number of employees $(-0.45 \%)$ is small and not significantly different from zero.

However, the firm-specific fixed effect regression (Model 1) does not account for any time-specific heterogeneity. It is therefore possible that the negative effects on firms in the city centres could be due to negative economic trends in small cities rather than an impact of the entry of external shopping malls. To account for this possibility, we incorporate time-specific fixed effects in our model, creating a generalized difference-in-differences model (Model 2 in Table 5). The results now show that the effects of the entry of new external shopping malls on the performance of firms located in the city centres of small cities are not significantly different from zero. In fact, neither real revenues nor employment of incumbent firms in the city centres are affected by the entry of external shopping malls. This finding suggests that it is easy to confuse the impacts of a long-term negative trend in labour productivity, real revenues, and employment for a negative impact caused by the establishment of new external shopping malls.

The Akaike information criterion (AIC) indicates that Model 2 is the best fit and thus further confirms that both firm- and time-specific fixed effects should be included to properly identify the entry effect of external shopping malls. 
Table 5. Effects of external shopping malls on the productivity of city centre firms

\begin{tabular}{lll}
\hline & Model 1 & Model 2 \\
\hline Coefficient & Coefficient \\
(p-value) & (p-value) \\
\hline Labour productivity & $-0.055^{* * *}$ & 0.000 \\
Effect & $(0.005)$ & $(0.996)$ \\
\hline Real revenues & $-5.31 \%^{* * *}$ & $0.01 \%$ \\
Effect & $-0.068^{* *}$ & 0.000 \\
\hline Employment & $(0.013)$ & $(0.997)$ \\
& $-6.62 \% * *$ & $-0.01 \%$ \\
Effect & -0.005 & 0.004 \\
\hline AIC (labour productivity) & 11192 & $(0.811)$ \\
\hline R-squared (labour & $0.754)$ & $0.37 \%$ \\
productivity) & $-0.45 \%$ & 11083 \\
\hline
\end{tabular}

${ }^{* * *}$ significant at the 0.01 level; ${ }^{* *}$ significant at the 0.05 level; * significant at the 0.1 level.

${ }^{a}$ The number of observations is lower for the model with employment and productivity as the dependent variables (19 953) than for the model with real revenues as the dependent variable (20 221) because some firms reported revenues but failed to report the number of employees.

\subsection{Validity and robustness checks}

A key assumption in our difference-in-differences identification strategy is that trends in our main outcome variable, labour productivity $\left(Y_{i t}\right)$, would have been parallel in treated and control cities in the absence of treatment. This assumption is impossible to test formally, but to give an indication of its validity, we follow Arcidiacono et al. (2020) and estimate an event study specification to investigate trends in the outcome variable in the treated cities before and after the entry of external shopping malls. If the treated and control cities have similar trends prior to entry, then we fail to reject 
the parallel trends assumption. For this event study, we first exclude the control cities from our dataset. Then, for the treated cities, i.e., the cities that have received new external shopping malls under our study period, we standardize the year variable so that the entry year is equal to zero. Hence, we obtain a dataset with 14 years before entry and 14 years after entry for our analysed sample of small cities. We then estimate the following regression model:

$$
\ln Y_{i t}=\beta_{0}+\sum_{t=-14}^{14} \beta_{\text {std_t }} \times \vartheta_{-} s t d_{t}+\vartheta_{t}+\gamma_{i}+\varepsilon_{i t},(4)
$$

where $\vartheta_{-} s t d_{t}$ denotes standardized years such that the specification allows the $\beta_{\text {std_t }}$ estimates to be interpreted as the effect on labour productivity for every standard year, both before and after entry. With all entry cities sharing a common entry year (at standard year $=0$ ), we can now illustrate the trends in the effects on the output variable (i.e., labour productivity) by standard year, before and after the establishment of external shopping malls, for both Model 1 (without time-specific fixed effects $\left(\vartheta_{t}\right)$ ) and Model 2 (with time-specific fixed effects $\left(\vartheta_{t}\right)$ ); see Figure 2 and Table A1 in Appendix 1.

In the figure depicted in 2(a), which corresponds to a model without correction for time trends, the parameter estimates are negative and seem to slightly trend downwards even before entry (i.e., before standard year $=0$ ). This result indicates that incumbents in entry cities both had lower levels of productivity and were on a more negative growth path even before the entry of external shopping malls. However, note that the year-by-year differences in levels of labour productivity between the entry and control cities are not statistically significant in the pre-entry periods.

The figure depicted in 2(b), corresponding to the model with time-specific controls, clearly indicates that before entry (i.e., before standard year $=0$ ), the 
estimates are not statistically significant, as the confidence intervals overlap the zeroline on the x-axis. This result implies that the pre-entry trends in entry and control cities for labour productivity, the main output variable in our study, are similar. The insignificant pre-entry trends correspond to the standardized years -13 to -1 in Table A1 (Appendix 1), columns 4 and 5 .

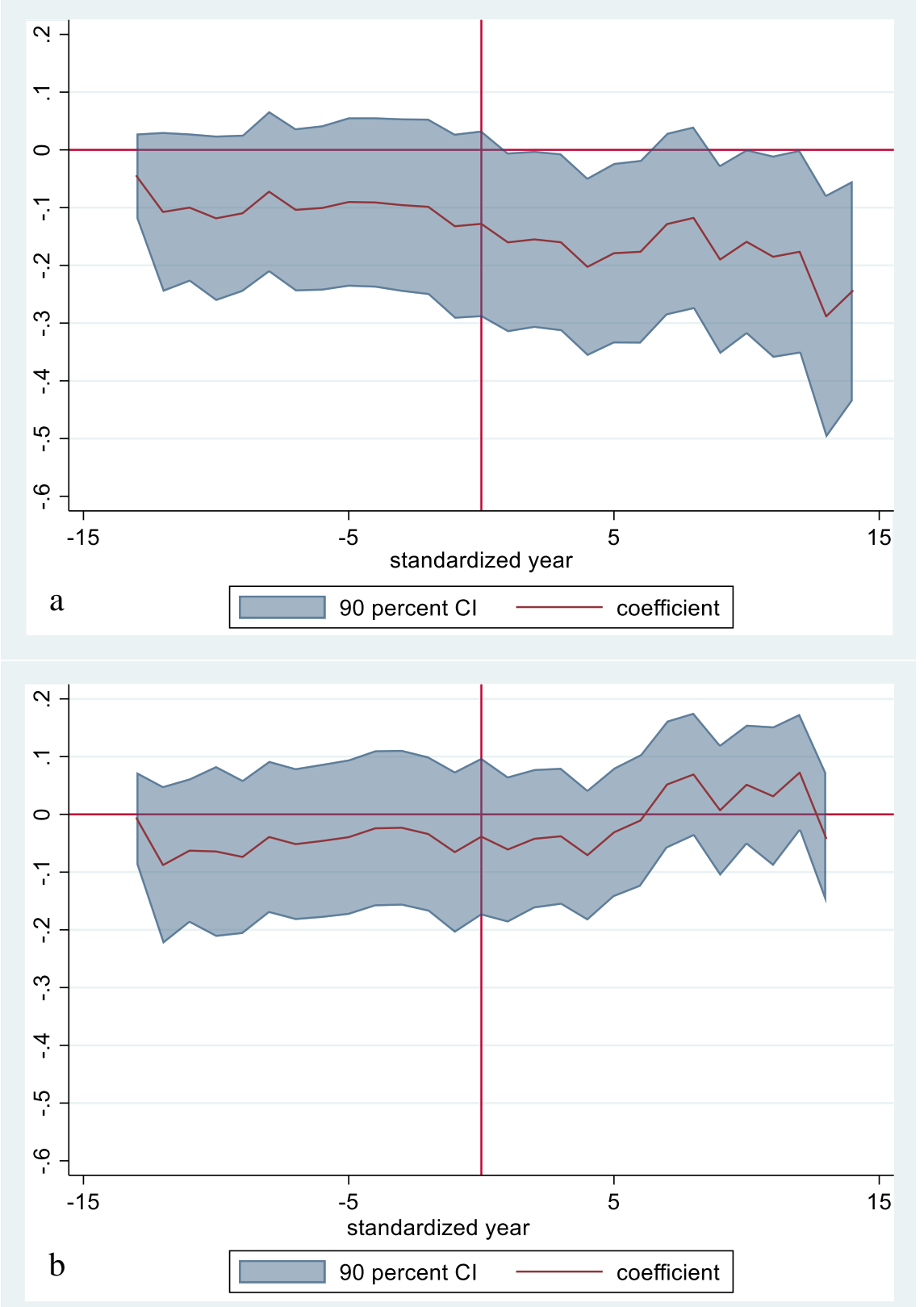

Figure 2. Trends in the effects on labour productivity in the entry cities by standardized year - model without time fixed effects (a) and model with time fixed effects (b) 
As neither the graphs nor the data in Table A1 (Appendix 1) offer a clear argument for or against significant pre-entry trends, we check the existence of differences in pre-entry trends between entry and control cities by regressing the parameter estimates $\left(P_{t}\right)$ from Models 1 and 2, respectively, on a trend variable for the standard years corresponding to the period before entry:

$$
P_{t}=\beta_{0}+\beta_{\text {trend }} \times \text { trend }+u_{t} . \text { (5) }
$$

The results indicate that $\beta_{\text {trend }}$ is small but negative and significant at $90 \%$ for the estimates from Model 1, while it is insignificant for the estimates from Model 2. This result confirms our conclusion that Model 1 shows a difference in trends violating the parallel trend assumption for difference-in-differences estimations, while in Model 2, no such difference in trends can be found after the inclusion of the time-specific fixed effects.

After the entry of external shopping malls, we observe a decline in labour productivity for the results corresponding to Model 1 (without time-specific fixed effects, Figure 2(a) and Table A1 (columns 2 and 3) in Appendix 1). In other words, some but not all coefficient estimates become negative and significant (Figure 2(a) and columns 2 and 3 in Table A1, Appendix 1) after the entry point. However, when controls are included for time trends (Figure 2(b) and columns 4 and 5 in Table A1, Appendix 1), the coefficient estimates are not statistically significant from zero after entry, confirming our main result that any negative effects on the incumbent firms in the city centres are not due to the entry of external shopping malls.

\section{Discussion}

When shopping malls enter in the outskirts of small cities, their range may overlap with the range of incumbent firms located in city centres. A larger size and a wider offer, 
often focused on higher-order goods, makes external shopping malls more attractive and gives them a competitive advantage over firms in city centres. These negative competition effects might, however, be offset by positive agglomeration effects. External shopping malls typically attract customers from farther away, which might result in positive spillover effects on firms located in city centres.

However, few studies have investigated the effects of shopping malls on incumbent firms in small cities. Rather, previous studies are based on the entry of bigbox stores in larger cities. This is problematic considering that the customer base is more limited in small cities, implying that external shopping malls may claim much of the city centre's old customer base. Furthermore, despite the small distances between the city centres and external shopping malls in these cities (generally under $1 \mathrm{~km}$ or approximately 0.6 miles), such positive spillovers due to increased opportunities for multipurpose or comparison shopping are likely quite limited. Due to their limited size and offers, the relative power of these small city centres to attract customers is often quite reduced compared to that of the new and larger external shopping malls, which means that the customer flow may be unidirectional, from the former towards the latter. At the same time, positive spillover effects due to agglomeration economies are also less likely to be strong in small cities because smaller city centre incumbents may not always have the necessary resources to capture knowledge spillovers and the local labour pool is quite limited. The limited number of studies that have investigated the development of incumbent firms in small cities following the entry of external shopping malls are typically case studies based on qualitative data; hence, they are unsuitable for drawing causal inferences.

We have contributed to the literature by investigating how incumbent firms in city centres were affected by the entry of 17 external shopping malls in the outskirts of 
small cities in Sweden. We have thus treated these entries as a natural experiment and estimated their effects on incumbent firms by applying a difference-in-differences model that accounts for both firm-specific heterogeneity and time trends. When we controlled only for firm-specific fixed effects, ignoring the impact of time trends, we found that incumbent firms experienced a productivity loss of $-5.31 \%$ due to the entry of external shopping malls. However, when we also accounted for time trends in the regression specification, all negative effects of external shopping malls on incumbent firms became insignificant.

Our results suggest that it is not new external shopping malls per se that negatively impact the performance of firms located in small cities; rather, the impact is from more general economic trends that these small cities have been experiencing for some time. Our findings challenge the results of earlier studies based on, for example, post-entry surveys (e.g., Howard and Davies 1993; Abdelghani 2013), which conclude that large shopping malls impact firms in city centres negatively. These studies that are based on qualitative research methods or more general regression models that do not account for time trends. Our results highlight the importance of distinguishing between the impacts of long-term negative trends from negative impacts caused by the establishment of new external shopping malls.

The downward development path of small cities is not surprising. RodríguesPose (2018) argued that such places have been for a long time regarded as 'places that do not matter' and characterized by economic decline and lack of opportunities and thus of investment. These places are lagging behind others because economic dynamism is increasingly related to large urban areas, implying that small cities in general have poor economic prospects for the future. Our results suggest that policy makers, rather than supporting laws to prevent the establishment of external shopping 
malls, should focus more on finding the hidden potential of these small places and facilitating more opportunities for small cities to become competitive. External shopping malls can even become an integrated part of this process through collaboration with city centres.

We believe that more research is needed to examine the effects of local policies enacted to increase the attractiveness of small cities, such as business improvement districts (Michel and Stein 2015; Wahlberg 2016). It is argued that these policies have the power to attract both residents and capital to the city centres of smaller cities, thus increasing their potential to benefit from agglomeration spillovers and simultaneously withstand competition from surrounding markets.

\section{Acknowledgements}

Research funding from The Swedish Retail and Wholesale Council (Handelsrådet) and the Research and Development Fund of the Swedish Tourism and Hospitality Industry (Besöksnäringens Forsknings- och Utvecklingsfond, BFUF), project number 2016-201, is gratefully acknowledged. 


\section{References}

Abdelghani, M.I.M. 2013. "The impact of shopping malls on traditional retail stores in Muscat: Case study of Al Seeb Wilayat”. In Wippel, S. (Ed.) Regionalizing Oman: Political, Economic, and Social Dynamic, Springer, pp. 227 - 250.

Ailawadi, K.L., Zhang, J., Krishna, A., and Kruger, M. 2010. When Wal-Mart enters: how incumbent retailers react and how this affects their sales outcomes. Journal of Marketing Research 47: 577 - 593.

Amcoff, J. 2003. ”Regional befolkningsomfördelning bland unga och gamla”. Institute for Future Studies Report No. 2003:13.

Arcidiacono, P., Ellickson, P.B., Mela, C.F., and Sigleton, J.D. 2020. The competitive effects of entry: Evidence from supercenter expansion. American Economic Journal: Applied Economics 12(3): 175 - 206.

Artz, G.M. and Stone, K.E. 2012. Revisiting Wal-Mart's impact on Iowa small-town retail: 25 years later. Economic Development Quarterly 26: 298 - 310.

Basker, E. 2007. "When good instruments go bad: A reply to Neumark, Zhang, and Ciccarella". University of Missouri - Columbia Working Paper No. 0706.

Brown, S. 1989. Retail location theory: the legacy of Harold Hotelling. Journal of Retailing 65: 450 - 470.

Chen, Y.-C., W.-T. Huang, and G.-H. Tzeng. 2010. A hybrid MCDM model for evaluating the environmental impacts of regional shopping centers. The Thailand Econometrics Society 2(2): 20 - 35.

Christaller, W. 1933. Central Places in Southern Germany. Englewood Cliffs, NJ: Prentice Hall.

Dart, J. 1988. Power, conflict, and satisfaction: Perceptions of shopping center based small retailers. American Journal of Small Business Winter: 35 - 44.

Daunfeldt, S.O., Mihaescu, O., Nilsson, H. and Rudholm, N. 2017. What happens when IKEA comes to town? Regional Studies 51(2): $313-323$.

Daunfeldt, S-O., Mihaescu, O., Nilsson, H., and Rudholm, N. 2019. Spillover effects when IKEA enters: Do local retailers win or lose? Papers in Regional Science 98(6): $2295-2313$.

Delic, M. and Knezevic, B. 2014. "Development of shopping centers in Central and Southeastern Europe”. In B. Katalinic (Ed.), Danube Adria Association for 
Automation and Manufacturing International Scientific Book, DAAAM International, pp. $471-484$.

Drewianka, S. and Johnson, D. 2006. "Wal-Mart and local labor markets, 1990 2004". University of Wisconsin Working Paper.

Ellickson, P.B., and Grieco, P.L.E. 2013. Wal-Mart and the geography of grocery retailing. Journal of Urban Economics 75: 1 - 14.

Erkip, F. and Özüduru, B.H. 2015. Retail development in Turkey: An account after two decades of shopping malls in the urban scene. Progress in Planning 102: 1- 33 . ESPON 2014. "European Spatial Planning Observation Network". Retrieved on 1 March 2018 from https://www.espon.eu/topics-policy.

Farhangmehr, M., Marques, S., and Joaquim, S. 2001. Hypermarkets versus traditional retail stores - Consumers' and retailers' perspectives in Braga: A case study. Journal of Retailing and Consumer Services 8(4): 189 - 198.

Forsberg, H. 1998. Institutions, consumer habits and retail change in Sweden. Journal of Retailing and Consumer Services 5(3): 185 - 193.

Foster, L., Haltiwanger, J., and Krizan, C.J. 2006. Market selection, reallocation and restructuring in the U.S. retail trade sector in the 1990s. Review of Economics and Statistics 88: $748-758$.

Freedman, M.L. and Kosova, R. 2012. Agglomeration, product heterogeneity and firm entry. Journal of Economic Geography 12(3): 601 - 626.

Ghosh, A. and McLafferty, S.L. 1987. Location Strategies for Retail and Service Firms. Lexington Books.

Glaeser, E.L. 2011. Triumph of the City: How Our Greatest Invention Makes Us Richer, Smarter, Greener, Healthier and Happier. Penguin Publishing Group.

González-Benito, J. and González-Benito, O. 2005. Environmental proactivity and business performance: An empirical analysis. Omega 33: 1- 15 .

Greenstone, M., Hornbeck, R., and Moretti, E. 2010. Identifying agglomeration spillovers: Evidence from winners and losers of large plant openings. Journal of Political Economy 118: 536 - 598.

Guimarães, P.P. 2014. The prospective impact of new shopping centers on the retail structure of Braga. Bulletin of Geography: Socio-Economic Series 25: 167 180.

Haltiwanger, J., Jarmin, R.R., and Krizan, C.J. 2010. Mom-and-pop meet big-box: Complements or substitutes? Journal of Urban Economics 67: 116 - 134. 
Han, M., Mihaescu, O., Li, Y., and Rudholm, N. 2018. Comparison and one-stop shopping after big-box retail entry: A spatial difference-in-difference analysis. Journal of Retailing and Consumer Services 40: 175 - 187.

Heffner, K. and Twardzik, M. 2015. The impact of shopping centers in rural areas and small towns in the outer metropolitan zone: The example of the Silesian Voidvodship. European Countryside 2: 87 - 100.

Henderson, J.V., Shalizi, Z., and Venables, A.J. 2001. Geography and development. Journal of Economic Geography 1: $81-105$.

Hicks, M.J., Keil, S.R., and Spector, L.C. 2012. Mom-and-pops or big-box stores: Some evidence of Wal-Mart impact on retail trade. Economic Development Quarterly 26(4): $311-320$.

Howard, E.B. and Davies, R.L. 1993. The impact of regional, out-of-town retail centres: The case of the Metro Centre. Progress in Planning 40: 89- 165 .

Jacobs, J. 1969. The Economy of Cities. Random House.

Jia, P. 2008. What happens when Wal-Mart comes to town: an empirical analysis of the discount retailing industry. Econometrica 76: 1263 - 1316.

Jones, K. and Doucet, M. 2000. Big-box retailing and the urban retail structure: The case of the Toronto area. Journal of Retailing and Consumer Services 7(4): 233 $-247$.

Lee, J. and Kim, Y. 2018. 'A Newcomer' versus 'First Mover': Retail location strategy for differentiation. The Professional Geographer 70 (1): 22 - 33.

Lee, Y. and McCracken, M. 2012. Centripetal and centrifugal movement: Shopping centres in Denver, USA, and Brisbane, Australia. Urban Studies 49(7): 1489 1506.

Lowe, M. 2005a. The regional shopping centre in the inner city: A study of retail-led urban regeneration. Urban Studies 42(3): $449-470$.

Lowe, M. 2005b. Revitalizing inner city retail? The impact of the West Quay development on Southampton. International Journal of Retail and Distribution Management 33(9): 658 - 668.

Maronick, T.J. 2007. Specialty retail center's impact on downtown shopping, dining, and entertainment. International Journal of Retail and Distribution Management 35(7): 556 - 568 . 
Maronick, T.J., and Stiff, R.M. 1985. The impact of a specialty retail center on downtown shopping behavior. Journal of the Academy of Marketing Science 13(3): $292-306$.

Marshall, A. 1890. Principles of Economics. McMillan and Co.

McCann, P. 2001. Urban and Regional Economics. Oxford University Press.

Michel, B. and Stein, C. 2015. Reclaiming the European city and lobbying for privilege: Business Improvement Districts in Germany. Urban Affairs Review 51(1): 74 98.

Monheim, R. 1998. Methodological aspects of surveying the volume, structure, activities and perceptions of city centre visitors. GeoJournal 45: 273 - 287.

Nordic Council of Shopping Centers (NCSC) 2017. "Swedish Shopping Center Directory". Online database. Accessed 1 March 2019 from: https://www.sscd.se.

Newmark, D., Zhang, J., and Cicarella, S. 2008. The effect of Wal-Mart on local labor markets. Journal of Urban Economics 63: 405 - 430.

O’Sullivan, A. 2003. Urban Economics. McGraw-Hill/Irwin.

Öner, Ö. 2014. "Retail location”. Jönköping International Business School Dissertation Series Dissertation No.097.

Özçelik, S.E. 2020. Evaluation of firm performances in emerging markets. In PerezUribe, R., Ocampo-Guzman, D., Salcedo-Perez, C., Pineiro-Cortes, L., RamirezSalazar, M.D.P. (Eds.) Handbook on Research on Increasing the Competitiveness of SMEs. IGI Global, pp. $329-354$.

Özüduru, B.H., Varol, C., and Yalçiner Erkoşkun, O. 2014. Do shopping centers abate the resilience of shopping streets? The co-existence of both shopping venues in Ankara, Turkey. Cities 36: 145-157.

Picone, G., Ridley, D., and Zandbergen, P. 2008. Distance decreases with differentiation: Strategic agglomeration by retailers. International Journal of Industrial Organization 27: 463-473.

Pine, B.J. and Gilmore, J.H. 1999. The Experience Economy: Work is Theatre \& Every Business a Stage. Harvard Business Press.

Porter, M.E. 1990. The Competitive Advantage of Nations. Free Press.

Pratt, S. och Pratt, L. 1960. The impact of some regional shopping centers. Journal of Marketing 25(2): 44 - 50. 
Rice, P., Venables, A.J., and Pattachini, E. 2006. Spatial determinants of productivity: Analysis for the regions of Great Britain. Regional Science and Urban Economics 36: 727 - 752 .

Rodrígues-Pose, A. 2018. The revenge of the places that don't matter (and what to do about it). Cambridge Journal of Regions, Economy and Society 11(1): 189 209.

Rudholm, N., Li, Y., and Carling, K. 2018. "How does big-box entry affect labor productivity in durable goods retailing? A synthetic control approach". HUI Research Working Paper No. 130.

Saito, H., and Gopinath, M. 2009. Plants' self-selection, agglomeration economies and regional productivity in Chile. Journal of Economic Geography 9: 539 - 558 .

SCB 2020. Befolkningsstatistik. Online database. Accessed 1 March 2020 from https://www.scb.se/hitta-statistik/statistik-efter-

amne/befolkning/befolkningens-

sammansattning/befolkningsstatistik/\#_Tabellerochdiagram.

Singh, V.P., Hansen, K.T., and Blattberg, R.C. 2006. Market entry and consumer behavior: an investigation of a Wal-Mart Supercenter. Marketing Science 25: $457-476$.

Stone, K.E. and McConnon, J.C.Jr. 1982. "The effect of shopping centers on host towns". Proceedings No. 279191 of the Annual Meeting of the American Agricultural Economics Association, 1 - 4 August, Logan, Utah, USA.

Van Handel, R.J. 1970. Uncertainty and retail location patterns. Applied Economics 2: $289-298$.

Wahlberg, O. 2016. Small town centre attractiveness: evidence from Sweden. International Journal of Retail and Distribution Management 44(4): 465 488.

Whysall, P. 1995. Regenerating inner city shopping centers. Journal of Retailing and Consumer Services 2(1): 3 - 13 .

Whysall, P. 2011. Managing decline in inner city retail centres: From case study to conceptualization. Local Economy 26(1): 3 - 17.

Wolinsky, A. 1983. Retail trade concentration due to consumers' imperfect information. The Bell Journal of Economics 14: 275 - 282.

Woolridge, J.M. 2010. Econometric Analysis of Cross Section and Panel Data. The MIT Press. 
Yalçiner Erkoşkun, O. and Özüduru, B.H. 2010. "The relation between retail activity transformation and social sustainability: A case study of Bahcelievler $7^{\text {th }}$ street, Ankara/Turkey". Proceedings of the $14^{\text {th }}$ International Planning History Society Conference, 12 - 15 July, Istanbul, Turkey.

Zhu, T., Singh, V., and Dukes, A. 2011. Local competition, entry and agglomeration. Quantitative Marketing and Economics 9: 129 - 154. 


\section{Appendix}

Table A1. Trends in the effects on labour productivity by standardized year in the entry cities

\begin{tabular}{|c|c|c|c|c|}
\hline \multirow[b]{2}{*}{ standardized year } & \multicolumn{2}{|c|}{ without time FE } & \multicolumn{2}{|c|}{ with time FE } \\
\hline & coefficient & p-value & coefficient & p-value \\
\hline standardized year -13 & -0.045 & 0.312 & -0.007 & 0.892 \\
\hline standardized year -12 & -0.108 & 0.202 & -0.088 & 0.291 \\
\hline standardized year -11 & -0.100 & 0.201 & -0.063 & 0.409 \\
\hline standardized year -10 & -0.119 & 0.174 & -0.064 & 0.475 \\
\hline standardized year -9 & -0.110 & 0.185 & -0.074 & 0.363 \\
\hline standardized year -8 & -0.072 & 0.394 & -0.039 & 0.625 \\
\hline standardized year -7 & -0.104 & 0.227 & -0.052 & 0.519 \\
\hline standardized year -6 & -0.101 & 0.248 & -0.046 & 0.570 \\
\hline standardized year -5 & -0.090 & 0.311 & -0.039 & 0.629 \\
\hline standardized year -4 & -0.091 & 0.310 & -0.024 & 0.768 \\
\hline standardized year -3 & -0.096 & 0.295 & -0.023 & 0.777 \\
\hline standardized year -2 & -0.099 & 0.288 & -0.034 & 0.677 \\
\hline standardized year -1 & -0.132 & 0.175 & -0.065 & 0.442 \\
\hline entry year & -0.128 & 0.193 & -0.039 & 0.642 \\
\hline standardized year 1 & $-0.160^{*}$ & 0.091 & -0.061 & 0.429 \\
\hline standardized year 2 & $-0.155^{*}$ & 0.096 & -0.042 & 0.565 \\
\hline standardized year 3 & $-0.160^{*}$ & 0.088 & -0.038 & 0.599 \\
\hline standardized year 4 & $-0.203^{* *}$ & 0.031 & -0.071 & 0.305 \\
\hline standardized year 5 & $-0.179^{*}$ & 0.060 & -0.031 & 0.647 \\
\hline standardized year 6 & $-0.176^{*}$ & 0.068 & -0.011 & 0.879 \\
\hline standardized year 7 & -0.129 & 0.181 & 0.052 & 0.442 \\
\hline standardized year 8 & -0.118 & 0.221 & 0.069 & 0.288 \\
\hline standardized year 9 & $-0.190^{*}$ & 0.057 & 0.007 & 0.919 \\
\hline standardized year 10 & -0.159 & 0.102 & 0.051 & 0.417 \\
\hline
\end{tabular}




\begin{tabular}{lllll} 
standardized year 11 & $-0.185^{*}$ & 0.082 & 0.031 & 0.671 \\
standardized year 12 & -0.176 & 0.100 & 0.072 & 0.243 \\
standardized year 13 & $-0.288^{* *}$ & 0.025 & -0.041 & 0.549 \\
standardized year 14 & $-0.244^{* *}$ & 0.035 & $\cdot$ & $\cdot$ \\
\hline
\end{tabular}

** significant at the 0.05 level; * significant at the 0.1 level.

Note: standardized year -14 is considered the base year and thus omitted from the regression model. 